\title{
Effect of Oral Sacchromycesboulardii Treatment Against Experimental Infection with Enterotoxigenic E.coli in Mice
}

\author{
Shahlaa M. Saleh*, Manhal F. Ahmed and Sabreen A.Hadi \\ Department of Biotechnology, College of Science, Al-Nahrain University. \\ *E-mail: shehlaam2006@yahoo.com.
}

\begin{abstract}
This study was designed to evaluate histological changes in intestine of mice treated with Sacchromycesboulardii and infected with enterotoxigenic Escherichia coli (ETEC). Twenty albino male mice were divided into four groups, and designated 1, 2, 3, and 4. Each group consisted of 5 mice and subjected to the followings treatments; Group1; used as a negative control.Group2; was infected with enterotoxigenic E.coli culture and use as positive control. Group3; was dosed with S.boulardii; Group4; was dosed with S.boulardii culture, and infected with ETEC E.coli. Histopathological study showed that infection of mice with ETEC causes a necrosis, degenerative changes and inflammatory cells infiltration in intestinal sections as compared with normal section taken from uninfected mice, while dosing with S.boulardii prevented the cytotoxic effect of ETEC in mice.
\end{abstract}

\section{Introduction}

Enterotoxigenic E. coli (ETEC) is a type of $E$. coli and the leading bacterial cause of diarrhea in the developing world, as well as the most common cause of traveler's diarrhea [1]. Each year, approximately 210 million cases and 380,000 deaths occur, mostly in children, from enterotoxigenic E. coli[2].

Disease caused by ETEC follows ingestion of contaminated food or water and is characterized by profuse watery diarrhea lasting for several days that often leads to dehydration and malnutrition in young children [3].

Numerous probiotic agents have been studied for the management of diarrheal disease. In particular, the prevention and management of acute viral diarrhea, the treatment of recurrent Clostridium difficile diarrhea, as well as the control of antibioticassociated diarrhea seem to be areas of significant potential benefit and few agents, including Lactobacillus rhamnosus GG, Lactobacillus reuteri, and $S$. boulardii ( $S$. boulardii), seem to be promising agents for the amelioration of the course of acute diarrhea in children when used therapeutically [4].

The yeast $S$. boulardii is a thermophilic, nonpathogenic administered in Western Europe for the prevention and treatment of a variety of diarrheal diseases [5]. Preclinical and experimental studies of $S$. boulardii have demonstrated an anti- inflammatory, antimicrobial, enzymatic, metabolic and antitoxinactivity [6].

The yeast $S$. boulardii secretes a 54-KDa protease which has been shown to neutralize certain bacterial toxins; $S$. boulardiiis also able to stimulate an immune response in the intestinal mucosa. It has a trophic effect by enhancing the metabolic function of the mucosa by releasing polyamines, which are implicated in stimulating the enzymatic activity of the colonic mucosa [7].This study was designed to assess the efficacy of $S$. boulardii in the treatment of diarrhoea caused by ETEC E. coli and parameter of assessment was studying histological alteration in the intestine of mice infected with $E$. coli.

\section{Materials and Methods \\ Microbial isolates}

Enterotoxigenic E.coli was supplied by Central Public Health Lab. and previously isolated from stool sample of infants suffering from diarrhea; $S$. boulardii was bought as commercial lyophilized yeast (Ultra-Levure $\AA$, BIOCODEX, France).

\section{Bacterial culture}

The bacterial strain E. coli was grown overnight at $37^{\circ} \mathrm{C}$ in brain heart infusion broth. This activated culture was centrifuged at 3,000 rpm for $5 \mathrm{~min}$, washed with sterile phosphatebuffered saline (PBS, $\mathrm{pH}$ 7.4), and resuspended in PBS to a final concentration of $2.5 \times 10^{7}$ bacteria/ml $[8]$. 


\section{S. boulardii culture}

The yeast $S$. boulardii was grown on Sabouraud Dextrose Agar medium for $48 \mathrm{hrs}$ at $28{ }^{\circ} \mathrm{C}$, and then cells were harvested and washed 3 times with PBS. Cells resuspended in PBS to a final concentration of $1 \times 10^{9}$ [9].

\section{Experimental design}

Twenty albino male mice were randomly divided into eight groups designated as 1, 2, 3, and 4. Each group consisted of 5mice, and subjected to the following treatments according to [10].

Group1: This group was used as a negative control.

Group2: This group was dosed with $0.1 \mathrm{ml}$. of $2.5 \times 10^{7} \mathrm{cfu} / \mathrm{ml} E$. coli culture and use as positive control.

Group3: This group was dosed with $0.1 \mathrm{ml}$ of $1 \times 10^{9} \mathrm{cfu} / \mathrm{ml} S$. boulardii culture.

Group4: This group was dosed with $0.1 \mathrm{ml}$ of $1 \times 10^{9} \mathrm{cfu} / \mathrm{ml} S$. boulardii culture, and infected with $0.1 \mathrm{ml}$ of $2.5 \times 10^{7} \mathrm{cfu} / \mathrm{ml}$ culture of E. coli.

Mice were dosed with a single dose $0.1 \mathrm{ml}$ of $1 \times 10^{9} \mathrm{cfu} / \mathrm{ml} \mathrm{S}$. boulardii culture daily by oral administration for 7 consecutive days. After 7 days of treatment, at the $8^{\text {th }}$ day of experiment period, each mouse was given $0.1 \mathrm{ml}$ of $2.5 \times 10^{7} \mathrm{E}$. coli culture by oral administration. After the $6^{\text {th }}$ day of infection with $E$. coli, mice were sacrificed by cervical dislocation and collected to evaluate histological effect. Pieces were taken from intestine and put in petridishes contain physiological salty solution to remove the fatty tissues and sticky bundles, then the organ was kept in test tubes containing 10\% formalin for about 16-18 hrs for fixation purpose, then they were transferred into tubes containing $70 \%$ ethanol alcohol in which they were preserved till the time of the finalpreparation [11]. The staining method was performed by using hematotoxilin and eosin [12].

\section{Results}

Mice intestinal sections were taken from the control group showednormal structure appearance of villi without any pathological changes as shown in Fig.(1A).

Results indicated in Fig.(1B), intestinal sections taken from mice infected with $E$. coli showed shedding and necrosis of intestinal mucosa and villi inside the lumen of the intestine.

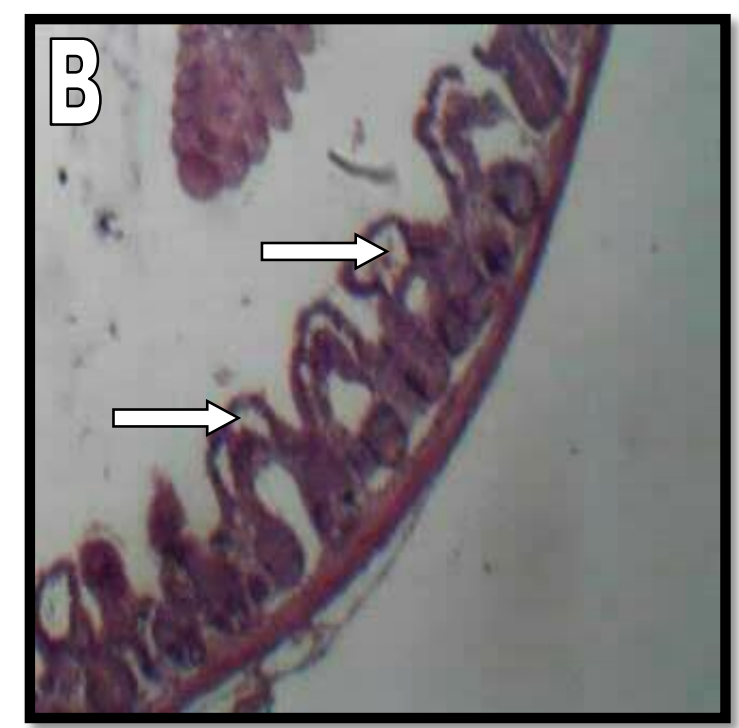

Fig. (1) (A) Section of intestine of normal mice showing normal structure appearance of intestinal vili

(B) Section in small intestine in mice infected with E. coli showing infiltration in the lamina properia in the middle of the villi with odema(arrows) $(\mathrm{HE}) \times 100$.

Group 3 was fed on the basal diet and was also dosed with $0.1 \mathrm{ml}$ of $\mathrm{S}$. boulardii figure

2Cshowing the normal appearance of intestine villi. Section of intestine showing normal structure appearance of intestine villi figure $2 D$ in mice treated with S.boulardii and infected with E. coli. 

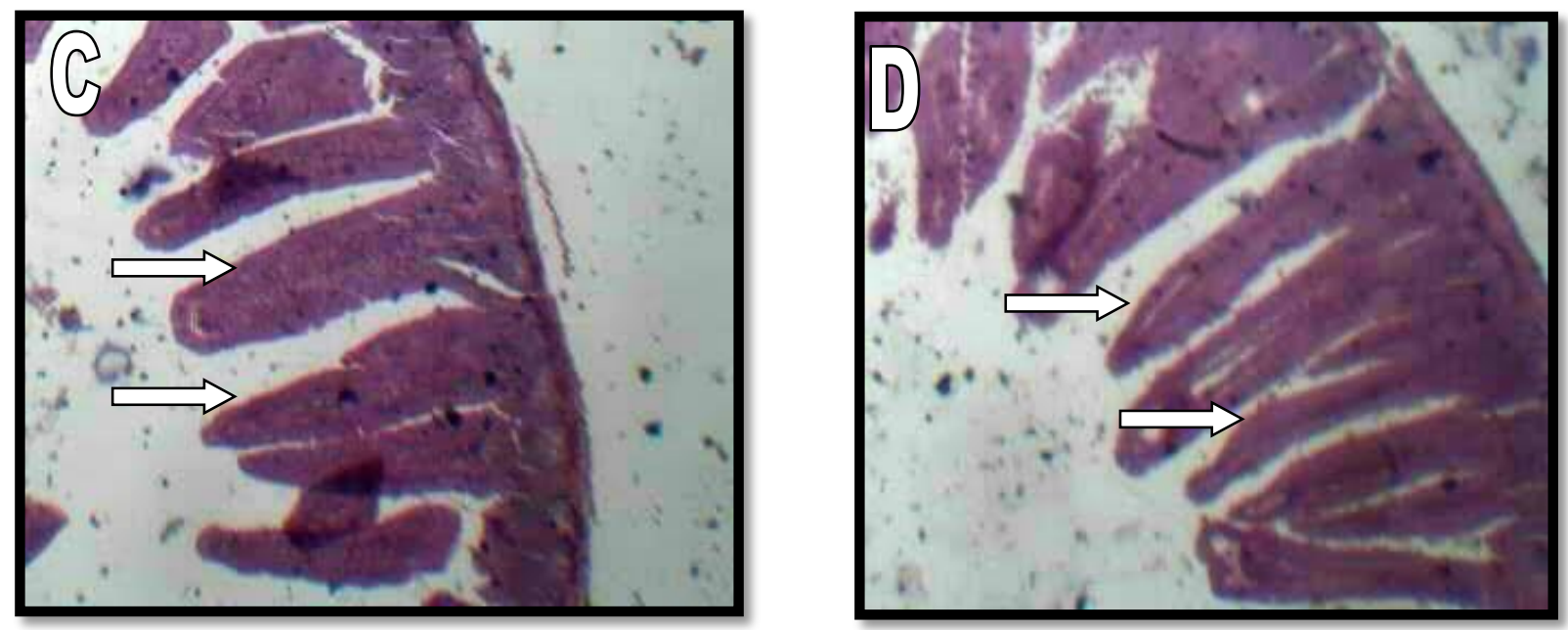

Fig. (2) (C) Section in small intestine in mice treated with $S$. boulardii showing normal villi appearance.

(D) Section in small intestine of mice treated with $S$. boulardii and infected with E. coli showing the villi look like normal appearance.

\section{Discussion}

Results indicated that the intestinal villus pattern of mice infected with ETECE.coli was markedly eroded; this might be causedby bacterial attachment to the epithelium of the intestinal tract and production of a toxin that acts locally on enterocytes. It is known that ETECE.coli produces two main types of toxins designated heat-labile (LT) and heatstable (ST) toxins. There are two forms of heat stable enterotoxin; STa andSTb[13, 14]. The bacterium colonize the GI tract by means of a fimbrialadhesin, e.g. CFA I and CFA II, and is noninvasive, but produces either the LT or ST toxin.

Mice treated with $S$. boulardii revealed a probiotic effect on intestinal sections. The probiotic effect of $S$. boulardii on the intestine could be due to its ability to adhere to cells in the Jejunum $[15,16]$, increasing brush border enzyme activity of lactase, alpha-glucosidase, and alkalinehosphatase, and increasing normal enterocyte maturation [17].

The intestinal villus pattern of mice treated with $S$. boulardii and infected with E.coli showing normal villi appearance. This may be attributed to antagonism effect of $S$. boulardii. A similar result was obtained by Geddek[18] who mentioned that the outer membrane of $S$. boulardi is rich in mannose, allowing pathogens such as E. coli, Salmonellae and other type 1 pili (mannose-binding fibers) containing pathogens to bind to this mannose rich membrane. This binding action prevents E. coli and other harmful bacteria from adhering to intestinal cells. This action may also be beneficial for other probiotic species as there is less competition for colonization.

Also, Dahan et al., [19] showed that $S$. boulardii has the capacity to release factors which neutralize bacterial toxins and decrease the deleterious effects of infectious pathogens. Another study showed that $S$. boulardii also produces a $63 \mathrm{kDa}$ protein phosphatase that inhibits the LPS toxicity of enterotoxigenic $E$. coli O55B5 byendotoxin dephosphorylation [20].

The beneficial effect of $S$. boulardii on C. rodentium-induced colitis was assessed in mice. This improvement effect of $S$. boulardii was associated with significantly reduced numbers of mucosal adherent bacteria compared with the infected untreated animals $(P \leq 0.05)$. This effect was not due to a bactericidal action but was correlated with a reduction in EspB and Tir protein secretions; respectively a translocator and an effector protein implicated in the type III secretion system (TTSS) [21].

This result came in accordance with Caetano et al., [22] who mentioned that $S$. boulardii also exerts a protective effect on epithelial cells infected with $E$. coli by decreasing the level of intracellular infection and reducing the apoptotic effect of E. coli on intestinal epithelium. 


\section{References}

[1] Nataro, J. P. and Kaper, J. B. "Diarrheagenic Escherichia coli Microbiology" Microbiol Rev.; 11:142 201, 1998.

[2] WHO "Future directions for research on enterotoxigenic scherichia coli vaccines for developing countries" Weekly Epidemiological Record. 81:97-104, 2006.

[3] Wenneras, C. and Erling, V. "Prevalence of enterotoxigenic Escherichia coliassociated diarrhoea and carrier state in the developing world" J. Health popul Natr. 22 (4):370-82, 2004

[4] Isolauri, E. "Probiotics for infectious diarrhea" Gut; 52: 436-437, 2003.

[5] McFarland, L. V. and Bernasconi P. "Saccharomyces boulardii: a review of an innovative biotherapeutic agent. Microb. Ecol. Health Dis. 6:157-171(1993).

[6] Czerucka, D.; Dahan, S.; Mograbi, B.; Rossi, B. and Rampal P. "Saccharomyces boulardii preserves the barrier functions and modulates the transduction pathway induced in enteropathogenic Escherichia coli-infected T84 cells" Infect. Immun. 68:5998-6004, 2000.

[7] Dahan, S.; Dalmasso, G. and Czerucka, D. "Saccharomyces boulardii interferes with enterohemorrhagic Escherichia coliinduced signaling pathways in T84 cells" Infect. Immun. 71: 766-773, 2003.

[8] Lilian, N.; Elizabeth, N. and Jacques, R. "Protection by Lactobacillus acidophilus ufv-h2b20 against experimental oral infection with Salmonella typhimuriumin gnotobiotic and conventional mice" Brazilian journal of microbiology 2001.

[9] Mahzounieh, M.; Karimi, T. and Marjianian, R. "The preventive of Saccharomyces boulardii in pathogenesis of Salmonella typhimurium in experimentally infected rats" Pak. J. of Bio.Scien., 9(4): 632-635, 2006.

[10] Lin, W.; Yu, B.; Lin, C. H.; wang, W. and Tsen, H.'Immune effect of heat-killed multistrain of Lactobacillus acidophilus against Salmonella typhimurium invasion to mice" .Appl. Microbiol.; 102(1):22-31, 2007.
[11] Bankroft, L. "Basic histological techniques" 4thed; an Arboerscience publishers. Pp: 130-145, 1980.

[12] Junqueria, L. and Carneiro, J. "Male Reproductive System" Basic Histology. Janson, M.; Harriet and Petery J., Stamford. 11th ed. Pp: 418- 434, 2005.

[13] Nagy, B. and Fekete, P. Z. "Enterotoxigenic Escherichia coli (ETEC) in farm animals" Veterinary Research, 30: 259-284, 1999.

[14] Nair, G. B. and Takada, Y. "Theheat labile and heat stable enterotoxins of Escherichia coli. In Escherichia coli Mechanisms of virulence, ed. Sussman, M.J. Cambridge University press, Cambridge, UK, 237-256, 1997.

[15] Cartwright-Shamoon, J.; Dickson, GR.; Dodge, J. and Carr, K. E."Up take of yeast (Saccharomyces boulardii) in normal and rotavirus treated intestine" Gut; 39:204209, 1996.

[16] Chapoy, P. "Intestinal mode of action of Saccharomyces boulardii" Gastroenterol Clin. Biol; 10:860-861, 1986.

[17] Jahn, H.; Ullrich, R. and Schneider, T. "Immunological and trophical effects of Saccharomyces boulardii on the small intestine in healthy human volunteers" Digestion; 57:95-104, 1996.

[18] Gedek, B. R. "Adherence of Escherichia coli sero group O 157 and the Salmonella typhimurium mutant DT 104 to the surface of Saccharomyces boulardii" Mycoses; 42(4):261-264, 1999.

[19] Buts, J. P.; Dekeyser, N.; Smets, F. and Sokal, E. "Saccharomyces boulardii produces in rat small intestine a novel protein phosphatase that inhibits Escherichia coli endotoxin by dephosphorylation" Pediatr. Res. 60, 2429, 2006.

[20] Dahan, S; Dalmasso, G.; Imbert, V.; Peyron, J. F.; Rampal, P. and Czerucka, D. "Saccharomyces boulardii interferes with enterohemorrhagic Escherichia coliinduced signaling pathways in T84 cells" Infect. Immun. 71: 766-773, 2003.

[21] Wu, X.; Vallance, B. A.; Boyer, L.; Buchan, A. M. and Jacobson, K. "Saccharomyces boulardii ameliorates Citrobacterrodentium-induced colitis 
through actions on bacterial virulence factors" Am. J. Physiol. Gastrointest. Liver Physiol. 294, G295-306, 2008.

[22] Caetano, J.A.; Parames, M.T. and Babo, M.J. "Immunopharmacological effects of Sacchaomyces boulardii in healthy human volunteers" Int. J. Immunopharmacol; 8:245-259,1986 .

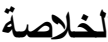

اجريت الدراسة لتقييم التغيرات النسيجية في امعاء

Sacchromyces boulardii الفئران المعالجة بخميرة والمصابة ببكتريا الـ E. coli المنتجة للسم الداخلي. درس التأثثر على •. بارة بيضاء والتي قسمت الى اربعة مجاميع وقد تضمنت كل مجموعة على ه فئران منساوية بالاعمار والاحجام. عدت المجموعة ( (1) سيطرة سالبة والمجموعة (ب) تم إصابتها ببكتربا الـ E. coli المنتجة للسم الداخلي (سيطرة

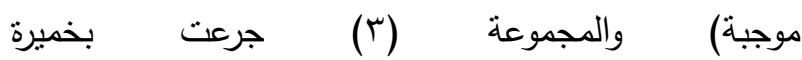
Sacchromycesboulardii بخميرة Sacchromycesboulardii ) وتم إصابتها ببكتريا الـ E. coli المنتجة للسم الداخلي. اظهرت نتائج الدراسة النسيجية ان اصابة الفئران بيكتريا E. coli تسبب بنتخرات وتغيرات انحلالية وارتشاح الخلايا الالتهابية في امعاء الفئران مقارنة بالمقاطع الطبيعية الماخودة من الفئران الغير مصابة.

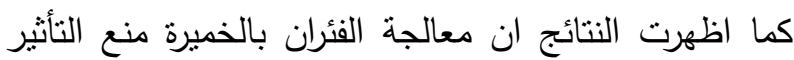
السام لبكتريا E. coli في الفئران المصابة. 